\title{
First molecular detection of Eimeria spp. in eared doves (Zenaida auriculata) from Brazil
}

\section{Primeira deteç̧ão molecular de Eimeria spp. em pombos (Zenaida auriculata) do Brasil}

\author{
Alessandra Taroda ${ }^{1}$; Luiz Daniel de Barros $^{2 *}$; Mércia de Seixas ${ }^{1}$; \\ Sérgio Tosi Cardim³; João Pedro Sasse ${ }^{1}$; Ana Flávia Minutti' ${ }^{1}$; Odilon Vidotto²; \\ João Luis Garcia
}

\section{Highlights:}

The epidemiology of Eimeria species in doves is scarce. A nested-PCR for detection of Eimeria spp. in fecal samples has been developed. Molecular detection of Eimeria spp. in Zenaida auriculata has been described worldwide for the first time.

\begin{abstract}
The aim of the present study was to detect Eimeria spp. in eared doves (Zenaida auriculata) from Brazil. Two hundred and fourteen birds were trap-capture in different regions of Londrina city, Paraná state, Southern Brazil. Fecal samples were collected, and DNA extraction was performed. A nested PCR based on the subunit I of the cytochrome c oxidase gene of the Eimeria mitochondrial genome was used to detect the DNA presence of this coccidian in eared dove feces. From 214 birds, 171 (79.9\%) were positive for Eimeria spp. There was significantly difference of positivity between the site of capture. When analyzing the genders, the numbers of positive males were $84 / 103(81.5 \%)$ and females $87 / 111$ (78.4\%). To the best of the authors' knowledge, this is the first study with molecular prevalence of Eimeria sp. in Z. auriculata. Further studies should be done to identify the species of Eimeria that infect eared doves $Z$. auriculata.
\end{abstract}

Key words: Eimeriidae. Coccidiosis. PCR. Columbiformes. Cytochrome c oxidase I gene.

\section{Resumo}

O objetivo do presente estudo foi detectar Eimeria spp. em pombos (Zenaida auriculata) do Brasil. Duzentos e quatorze pombos foram capturados em diferentes regiões da cidade de Londrina, estado do Paraná, Sul do Brasil. Amostras fecais foram coletadas e realizada a extração de DNA. Uma nested-PCR baseada na subunidade I do gene oxidase do citocromo c oxidase do genoma mitocondrial de Eimeria spp. foi utilizada para detectar a presença de DNA deste coccídeo nas amostras fecais dos pombos. Das 214 aves, 171 (79,9\%) foram positivas para Eimeria spp. Houve uma diferença significativa de positividade entre o local de captura. Quando analisado o gênero, o número de machos positivos foi $84 / 103(81,5 \%)$ e fêmeas 87/111 (78,4\%). Para o conhecimento, este é o primeiro estudo com prevalência

1 Discentes de Doutorado, Universidade Estadual de Londrina, UEL, Londrina, PR, Brasil. E-mail: aletaroda@gmail.com; mercia_seixas@yahoo.com.br; joaosasse@hotmail.com; aninha_minutti@hotmail.com

2 Prof. Drs., Universidade Estadual de Londrina, UEL, Londrina, PR, Brasil. E-mail: luizdanielbarros@gmail.com; vidotto@uel. br; joaoluisgarcia10@gmail.com

3 Prof., Universidade Norte do Paraná, UNOPAR, PR, Arapongas, PR, Brasil. E-mail: stcardim@hotmail.com

* Author for correpsondence 
molecular de Eimeria spp. em Z. auriculata. Novos estudos devem ser conduzidos para identificar as espécies de Eimeria que infectam pombos Z. auriculata.

Palavras-chave: Eimeriidae. Coccidiose. PCR. Columbiformes. Citocromo c oxidase I gene.

\section{Introduction}

The eared dove (Zenaida auriculata) is found in most of Latin America countries in both urban and rural areas (Adriano \& Cordeiro, 2001). It belongs to the family Columbidae, which comprises over than 300 avian species worldwide (Jamriška \& Modrý, 2012). In Londrina region, it has been described 10 Columbidae species, including $Z$. auriculata (Shibatta et al., 2009).

Eimeria is the most diverse coccidia from Order Eucoccidiorida, causing damages in all classes of vertebrates (Berto, McIntosh, \& Lopes, 2014) Eimeriosis has been causing losses especially in poultry industry for its high pathogenicity (Cardozo \& Yamamura, 2004; Reid et al., 2014) There are many species of Eimeria described infecting pigeons such as: E. labbeana, E. columbarum, E. columbae, E. tropicalis, E. kapotei, E. janovyi, E. livialis, E. sphenocerae, E choudari, E. turturi, E. waiganiensis, E. duculai, E. gourai, E. palumbi, E. curvata, E. zenaidae, E. mauritiensis and E. columbapalumbi (Ball, Daszak, Swinnerton, Jones, \& Snow, 2012; Yang, Brice, Elloit, \& Ryan, 2016a).

Over the years, the methodologies to diagnose Eimeria in birds have been developed, not only in the traditional morphologic characterization, but also in molecular biology (Carvalho et al., 2011). Furthermore, the identification of Eimeria species can be based on morphology, geographic distribution, host species and pathology (Yang, Brice, Elloit, Lee, \& Ryan, 2014). In this way, molecular tools are used for diagnostics and to describe the genetic variability of Eimeria oocysts (Carvalho et al., 2011)

The sequences of the subunit I of the cytochrome c oxidase gene (COI) have been used to identify Eimeria and Isospora species in birds; however, there are still few studies of coccidia in birds worldwide (Berto et al., 2014; Hafeez et al., 2015; Ogedengbe, Hanner, \& Barta, 2011; Rathinam, Gadde, \& Chapman, 2015; Yang, Brice, \& Ryan, 2016b). Thus, the aim of this study was to verify the presence of Eimeria sp. in Z. auriculata from Southern Brazil.

\section{Material and Methods}

Study location and sampling

Londrina city is located at Parana State, Southern Brazil $\left(23^{\circ} 08^{\prime} 47^{\prime \prime}\right.$ to $23^{\circ} 55^{\prime} 46^{\prime \prime} \mathrm{S}, 50^{\circ} 52^{\prime} 23^{\prime \prime}$ to $51^{\circ} 19^{\prime} 11^{\prime \prime}$ W). Between January 2010 and December 2011, 214 male and female eared doves (Z. auriculata) were trap-captured in four different locations in Londrina: State University of Londrina Campus (University: $n=54$ ), Crop Cooperative I (Coop. I: $n=136)$, Dairy Farm $(n=16)$ and Crop Cooperative II (Coop. II: $n=9$ ).

The birds were euthanized in a $\mathrm{CO}_{2}$ chamber, and during the autopsy, the intestines were collected and opened. The fecal samples were scraped from the guts, put into plastic microtubes and maintained at $-20{ }^{\circ} \mathrm{C}$ until DNA extractions.

All procedures involving the animals was approved by the National Institute for the Environment and Renewable Natural Resources (IBAMA - SISBIO N. 16428-1) and by the Ethics Committee of Animal Experiments of the State University of Londrina (n. 70/2008). The birds were euthanized according to the guidelines of the National Council for Animal Experimental Control (CONCEA/Brazil).

\section{DNA extraction}

Before the DNA extraction procedures, fecal samples were submitted to three cycles of freeze 
and thaw (freezer $-80{ }^{\circ} \mathrm{C}$ and water bath $55^{\circ} \mathrm{C}$ ). For the DNA extraction, $1 \mathrm{~mL}$ of Tris-EDTA (TE) was added for each $50 \mu \mathrm{L}$ of fecal sample in a 1.5 $\mathrm{mL}$ microtube. After centrifugation $(4000 \mathrm{~g}$ for $15 \mathrm{~min}$ ), the supernatant was discarded, and the pellet was used for extraction with Nucleospin Tissue $^{\circledR}$ (Macherey-Nagel, Germany) according with manufacturer's instructions. DNA sample was eluted in $20 \mu \mathrm{l}$ of elution and stored at $-20{ }^{\circ} \mathrm{C}$ until further analysis.

\section{$P C R$}

A nested PCR based on detecting sequences in the subunit I of the cytochrome c oxidase gene (COI) of the Eimeria mitochondrial genome was performed according with methodology previously described (Dolnik, Palinauskas, \& Bensch, 2009) molecular studies of wild birds' Coccidia are still in their infancy and are mostly based on DNA extracted from the blood stages of these parasites. Linking microscopic and molecular data requires a method that reliably extracts DNA from single oocysts with parallel detailed morphological examination of the same cell. We offer a thorough manual of isolating, photographing, and trapping single oocysts from avian feces, followed by extraction of parasite DNA and amplification of mitochondrial DNA from the same cells. In 39 single oocysts from 6 wild blackcaps, we combined microscopic studies of individual cells with studies on their mitochondrial haplotype. In $72 \%$ of the single oocysts sampled, we detected unambiguous sequences. From feces and blood of investigated birds, we obtained 6 different haplotypes of Isospora sp. (iSAT1-iSAT 6.

The first PCR was performed using the external primers COX tenella $\mathrm{F}^{\prime} \quad\left(5^{\prime} \mathrm{G}(\mathrm{AT})\right.$ TCATTAGTATGGGCACATCA3') and COX tenella $\mathrm{R}$ (5'CCAAGAGATAATAC(AG)AA(AG) TGGAA3'). The second round was performed with the internal primers COX tenella $\mathrm{F} 2$ (5'GGGCACATCATATGATGAC3') and COX tenella R2 (5'ATAGTATGTATCATGTA(AG)(AT)GCAA3').
For the DNA amplification, $0.8 \mu \mathrm{M}$ of each primer, PCR mixture (0,2 mM of each dNTPs, 2.5 $\mathrm{mM} \mathrm{MgCl2}$, 1X PCR Buffer (Invitrogen, USA) and $1.25 \mathrm{U}$ of Platinum Taq DNA polymerase (Invitrogen, USA) were added to $2 \mu \mathrm{L}$ of isolated DNA. The first PCR was carried out in an Applied System Termocycle ${ }^{\circledR}$ (Applied Biosystems, USA) under the following conditions: $94^{\circ} \mathrm{C}$ for $3 \mathrm{~min}, 12$ cycles at $94{ }^{\circ} \mathrm{C}$ for $30 \mathrm{sec}, 57^{\circ} \mathrm{C}$ for $30 \mathrm{sec}$ and 72 ${ }^{\circ} \mathrm{C}$ for $30 \mathrm{sec}, 15$ cycles at $94{ }^{\circ} \mathrm{C}$ for $30 \mathrm{sec}, 48{ }^{\circ} \mathrm{C}$ for $30 \mathrm{sec}$ and $72^{\circ} \mathrm{C}$ for $30 \mathrm{sec}$, and a final extension at $72^{\circ} \mathrm{C}$ for $10 \mathrm{~min}$. Two microliters of the first PCR product were used in the second amplification. This second PCR was carried out under the following conditions: $94{ }^{\circ} \mathrm{C}$ for $3 \mathrm{~min}, 35$ cycles at $94^{\circ} \mathrm{C}$ for $30 \mathrm{sec}, 50^{\circ} \mathrm{C}$ for $30 \mathrm{sec}$ and $72^{\circ} \mathrm{C}$ for $30 \mathrm{sec}$, and a final extension at $72^{\circ} \mathrm{C}$ for $10 \mathrm{~min}$. Samples with $250 \mathrm{bp}$ length bands were considered positive.

A positive control (genomic DNA from Eimeria acervulina obtained from experimentally infected chicken) and negative control (ultrapure water) were included in each PCR reactions. The amplified fragments from the second PCR were visualized under ultraviolet light after the electrophoresis in $1.5 \%$ agarose gel stained with $\mathrm{SYBR} \AA$ Safe (Invitrogen, USA) and photodocumented by LPix Imagem ST Software (Loccus Biotecnologia). A 100 bp DNA ladder (Invitrogen, USA) was used in each agarose gel.

\section{Statistical analysis}

The Chi-square $(\chi 2)$ test corrected by Yates was used to compare the locations of capture and gender using the Epi Info software, version 6 (Dean et al., 1994). A p-value of $\leq 0.05$ was considered significant.

\section{Results and Discussion}

Out of 214 birds, 171 (79.9\%) were positive for Eimeria sp. by nPCR. There was a significantly difference of positivity between the places of 
capture $(\mathrm{p}=0.0008)$, since there were more positive birds from Coop. I $(119 / 136,87.5 \%)$ than in the University $(33 / 54,61.1 \%)$, the Dairy Farm (12/15,
$80 \%)$ and the Coop. II $(7 / 9,77.8 \%)$ as shown in Table 1.

Table 1

Association between the number of positive Zenaida auriculata for Eimeria detection by PCR in different site capture from Southern Brazil

\begin{tabular}{|c|c|c|c|c|c|c|c|}
\hline \multirow{2}{*}{ Capture site } & \multirow{2}{*}{$\mathrm{N}$} & \multicolumn{2}{|c|}{ Positive } & \multicolumn{2}{|c|}{ Negative } & \multirow[b]{2}{*}{$\mathrm{X}^{2}$} & \multirow[b]{2}{*}{$\mathrm{P}$} \\
\hline & & $\mathrm{n}$ & $\%$ & $\mathrm{n}$ & $\%$ & & \\
\hline University a & 54 & 33 & 61.1 & 21 & 38.9 & 16.79 & 0.0008 \\
\hline Crop Coop. $\mathrm{I}^{\mathrm{b}}$ & 136 & 119 & 87.5 & 17 & 12.5 & & \\
\hline Dairy Farm a,b,c & 15 & 12 & 80.0 & 3 & 20.0 & & \\
\hline Crop Coop. II a,b,c & 9 & 7 & 77.8 & 2 & 22.2 & & \\
\hline TOTAL & 214 & 171 & 79.9 & 43 & 20.1 & & \\
\hline
\end{tabular}

$\mathrm{N}=$ total number of samples, $\chi 2=$ qui-square, $\mathrm{p}$-value, different letters: $\mathrm{a}, \mathrm{b}, \mathrm{c}$ and $\mathrm{d}$ indicate significant differences $(\mathrm{p}<0.05)$ in prevalence for the different places.

When analyzing the genders, $103 / 214(48.13 \%)$ were male and 111/214 (51.87\%) were female. The number of positive males were $84 / 103(81,5 \%)$ and females $87 / 111(78,4 \%)$, which showed no statistical differences between the genders $(p>0.05)$ and no differences when comparing the genders regarding the capture sites $(\mathrm{p}>0.05)$.

To the author's knowledge, this is the first study with molecular prevalence of Eimeria sp. in Z. auriculata in Brazil. Yang et al. (2016b) studying Eimeria from Columba livia domestica in Australia, using the COI gene, described a new species named Eimeria labbeana-like. Most of the molecular characterization of Eimeria oocysts were done in chickens and turkeys (Hafeez et al., 2015; Ogedengbe et al., 2011; Rathinam et al., 2015)Springer-Verlag Berlin Heidelberg. Speciesspecific PCR primers targeting the mitochondrial cytochrome c oxidase subunit I (mtCOI, and despite over than 1700 species have been described in different hosts (Yang et al., 2014), there is still a lack of information about Eimeria in other birds, including Columbiformes.
A significantly difference was observed between the positivity on samples and the capture sites, especially when analyzing the results from the University and those from Coop. I. This might be because there were more eared doves captured from Coop I, giving a higher prevalence of Eimeria in this place, or because the $Z$. auriculata population from there site was much bigger than the one found at the University. The bigger the population, the higher amount of feces to be in contact with, the most birds can be affected. As these birds live in flocks (Adriano \& Cordeiro, 2001; Shibatta et al., 2009), they can get infected rapidly from themselves and keep the Eimeria in the population.

There was no statistical importance between the genders, demonstrating that both male and female get infected equally. This can be due to their life in flocks and all of them feed on the ground even during the breeding. It is also important as the young population can get infected, and although most of free-living birds present asymptomatic infections, even if they shed oocysts, eimeriosis is reported to damage strongly the young birds, 
which can shed more oocysts in the environment, depending on inoculation dose, stress, previous infection, coinfection with other diseases and immunocompetence (Atkinson, Thomas, \& Hunter, 2009; Cole \& Friend, 1999).

Most of studies with Eimeria in pigeons around the world were done with the prevalence of oocyst shedding and morphometric descriptions: in 1991, McQuistion (1991) found a new coccidian in Zenaida galapagoensis, named as Eimeria palumbi, at the Galapagos Island. Conti \& Forrester (1981) studied two populations of Zenaida macroura and one population of Zenaida asiatica in Florida, USA and they found Eimeria sp. in $33.3 \%, 49.1 \%$ and $6 \%$ doves, respectively. In Brazil, Adriano, Thyssen, and Cordeiro (2000) described Eimeria curvata n. sp. in 8/46 Columbina talpacoti and 5/39 Scardafella squamatta. A few years later, Adriano, Thyssen and Cordeiro (2003), based on morphological characteristics of oocysts, first described a new species of Eimeria in Z. auriculata, named Eimeria zenaidae n. sp. González et al. (2004) studied Z. auriculata in Chile and found 5.5\% (13/235) of then shedding oocysts of E. labbeana. These studies show a diversity of species that can be found in doves and the importance to research Eimeria worldwide. As Eimeria shows a specificity for hosts, it must be given relevancy to the knowledge of species infecting each kind of bird.

Some studies with other species of pigeons also found Eimeria oocysts in feces by flotation methods. Sari, Karatepe, Karatepe and Kara (2008) studied 136 domestic pigeons (Columba livia) and 115 wild pigeons in Turkey, by Sheather's method. They found $81 / 136(59.6 \%)$ positive domestic pigeons and $35 / 115(30.4 \%)$ wild pigeons with coccidian oocysts. They identified E. labbeana, E. columbarum, E. columbae and Isospora sp. through morphology, which reveals that the birds can be infected by more than one species of coccidia spread in the environment.

Natala et al. (2009) also using Sheather's method, found $49.2 \%$ of positive birds for Eimeria sp., while
Radfar, Fathi, Asl, Dehaghi and Seghinsara (2011) identified 41 (40.19\%) of pigeons with Eimeria sp. in Iran. In Brazil, Marques, Cuadros, Silva and Baldo (2007) found 37/43 (86.05\%) of domestic pigeons with Eimeria sp. oocysts. Ball et al. (2012) described for the first time the Eimeria mauritiensis in Nesoenas mayeri in Mauritius Island. In the same year, Jamriška and Modrý (2012) described Eimeria columbapalumbi n. sp. for the first time, from Columba palumbus in Czech and Slovak Republics. Aleksandra and Pilarczyk (2014)the degree of coccidia infection and the effect of the coccidiostat used in the course of the disease in two pigeon lofts located in the West Pomerania province. The material for the study came from 180 birds. A total of 330 faecal samples were investigated with two methods: Willis-Schlaafs (qualitative studied 180 Columba livia from two different lofts in a husbandry in West Pomerania Province. They had respectively in loft I and loft II: 17/19 (89\%) and 62/67 (93\%) of young pigeons, $27 / 43(63 \%)$ and 28/51 (55\%) of adult pigeons with Eimeria sp. Morphologically, the oocysts found were described as E. labbeana, $E$. columbarum and E. columbae. Yang et al. (2016b) first described an Eimeria labbeana-like from a Columba livia domestica attended in a rehabilitation center in Australia. All this data determine that Columbiformes are infected by different Eimeria and although some pigeons show specific species of Eimeria, the same species of pigeons show the same range of Eimeria. As Z. auriculata is spread over the Latin America, we can deduce that we can find the same Eimeria in different countries as the ones found in Brazil.

Most of these studies showed higher presence of oocysts in fecal samples, but it does not seem to be related to the total number of samples. The high prevalence found in $Z$. auriculata in this study (79.91\%) by PCR can be due to the scraped samples, which could have brought not only DNA from oocyst free on stool, but also DNA from other intracellular stages of Eimeria (e.g. sporozoites, meronts). 
Molecular methods are needed to complement morphological data, as it may not be enough to give full information about species identity and host specificity. Furthermore, molecular characterization might show the genetic diversity, the phylogenetic relationships and provide information about the geographic distribution. However, PCR methods can underestimate mixed infections, that can sometimes be observed as double peaks on sequence electopherogram, as the sequencing selects the amplification of only one species of parasite (PérezTris \& Bensch, 2005; Valkiūnas et al., 2006, 2008) and resolving such multiple infections is important for our understanding of host-parasite relationships. We propose a simple and reasonably accurate method for detecting and resolving multiple infections, based on the analysis of parasite cytochrome $b$ DNA sequences: genetically mixed infections are first identified by double nucleotide peaks on sequence electropherograms, and later retrieved by TA-cloning. We applied this method to wild birds, and to experimentally created mixes with varying proportion of two parasites ( Plasmodium spp. and Haemoproteus spp..

PCR studies with Eimeria in pigeons are still limited, so little is known about genetic characterization of this parasites in Columbiformes. As nuclear genomics has shown a lack of reliability on speciation, researchers employed the mitochondrial COI sequence as an alternative marker for molecular identification. Although the usage of COI gene has been increasing in the last few years, there is still not many information in public databases about coccidian COI sequences (Berto et al., 2014) which is why molecular studies about COI genes are important to understand the coccidia, such as the present research. Moreover, the sequencing is needed to describe the genetic characterizations of the species.

\section{Conclusions}

The evaluation of Eimeriidae coccidia species is very important not only to contribute to taxonomy and phylogeny, but to estimate the risk of infection of other bird species that could be living at the same environment of $Z$. auriculata. Eimeria spp. in Z. auriculata was first molecularly described in the present study. Further studies should be done in order identify the Eimeria species that infect $Z$. auriculata.

\section{Acknowledgements}

This study recived financial support from the Coordenação de Aperfeiçoamento de Pessoal de Nível Superior (CAPES, AUX-PEPARASITOLOGIA-1345/2011, 10259/12-0). J.L. Garcia and O. Vidotto are recipients of CNPq fellowships.

\section{References}

Adriano, E. A., \& Cordeiro, N. S. (2001). Prevalence and intensity of Haemoproteus columbae in three species of wild doves from Brazil. Memórias do Instituto Oswaldo Cruz, 96(2), 175-178. doi: 10.1590/S007402762001000200007

Adriano, E. A., Thyssen, P. J., \& Cordeiro, N. S. (2000). Eimeria curvata n. sp. (Apicomplexa: Eimeriidae) in Columbina talpacoti and Scardafella squammata (Aves: Columbidae) from Brazil. Memorias do Instituto Oswaldo Cruz, 95(1), 53-55. doi: 10.1590/ S0074-02762000000100008

Adriano, E. A., Thyssen, P. J., \& Cordeiro, N. S. (2003). A new species of Eimeria from the eared dove Zenaida auriculata (Aves: Columbidae) in Brazil. Acta Protozoologica, 42(1), 71-73.

Aleksandra, B., \& Pilarczyk, B. (2014). Occurrence of coccidia infection in pigeons in amateur husbandry. Diagnosis and prevention. Annals of Parasitology, 60(2), 93-97. PMID: 25115060

Atkinson, C. T., Thomas, N. J., \& Hunter, D. B. (2009). Parasitic diseases of wild birds. In Parasitic Diseases of Wild Birds. Wiley-Blackwell. doi: 10.1002/9780813804620

Ball, S. J., Daszak, P., Swinnerton, K. R., Jones, C. G., \& Snow, K. R. (2012). A new species of Eimeria (Apicomplexa: Eimeriidae) from the endangered pink pigeon, Nesoenas mayeri (Prévost, 1843) Cheke, 2005 (Columbiformes) in Mauritius. African Zoology, 47(2), 369-372. doi: 10.3377/004.047.0203 
Berto, B. P., McIntosh, D., \& Lopes, C. W. G. (2014). Studies on coccidian oocysts (Apicomplexa: Eucoccidiorida). Revista Brasileira de Parasitologia Veterinária, 23(1), 1-15. doi: 10.1590/S198429612014001

Cardozo, S. P., \& Yamamura, M. H. (2004). Parasitas em produção de fragos no sistema de criação tipo colonial/ caipira no Brasil. Semina: Ciências Agrárias, 25(1), 63-74. doi: 10.5433/1679-0359.2004v25n1p63

Carvalho, F. S., Wenceslau, A. A., Teixeira, M., Matos Carneiro, J. A., Melo, A. D. B., \& Albuquerque, G. R. (2011). Diagnosis of Eimeria species using traditional and molecular methods in field studies. Veterinary Parasitology, 176(2-3), 95-100. doi: 10.1016/j.vetpar.2010.11.015

Cole, R. A., \& Friend, M. (1999). Intestinal Coccidiosis. In M. Friend \& J. C. Franson (Ed.), Field manual of wildlife diseases (Chapter 26, pp. 207-213). Madison: National Wildlife Health Center.

Conti, J. A., \& Forrester, D. J. (1981). Interrelationships of parasites of white-winged doves and mouring dobes in Florida. Journal of Wildlife Diseases, 17(4), 529-536. doi: 10.7589/0090-3558-17.4.529

Dean, A. G., Dean, J. A., Coulombier, D., Brendel, K. A., Smith, D. C., Burton, D. H., Dicker, R. C.,... Arner, T. G. (1994) EpiInfo, Version 6: A word Processing, Database, and Statistic Program for Epidemiology on Microcomputers. Georgia: Center for Diseases Control and Prevention.

Dolnik, O. V., Palinauskas, V., \& Bensch, S. (2009). Individual oocysts of Isospora (Apicomplexa: Coccidia) parasites from avian feces: From photo to sequence. Journal of Parasitology, 95(1), 169-174. doi: $10.1645 / \mathrm{GE}-1873.1$

González, D., Daugschies, A., Rubilar, L., Pohlmeyer, K., Skewes, O., \& Mey, E. (2004). Fauna parasitaria de la tórtola común (Zenaida auriculata, de Murs 1847) (Columbiformes: Columbidae) en Ñuble, Chile. Parasitología Latinoamericana, 59(1-2), 3741. doi: 10.4067/S0717-77122004000100007

Hafeez, M. A., Shivaramaiah, S., Dorsey, K. M., Ogedengbe, M. E., El-Sherry, S., Whale, J.,... Barta, J. R. (2015). Simultaneous identification and DNA barcoding of six Eimeria species infecting turkeys using PCR primers targeting the mitochondrial cytochrome c oxidase subunit I (mtCOI) locus. Parasitology Research, 114(5), 1761-1768. doi: 10.1007/s00436-015-4361-y

Jamriška, J., \& Modrý, D. (2012). A new species of Eimeria Schneider, 1875 (Apicomplexa: Eimeriidae) from the common wood pigeon Columba palumbus Linnaeus, 1758 (Aves: Columbidae). Acta Protozoologica, 51(4), 329-333. doi: 10.4467/16890027AP.12.026.0786

Marques, S. M. T., de Cuadros, R. M., Silva, C. J. da, \& Baldo, M. (2007). Parasites of pigeons (Columba livia) in urban areas of lages, Southern Brazil. Parasitología Latinoamericana, 62(3-4), 183-187. doi: $10.4067 / \mathrm{S} 0717-77122007000200014$

McQuistion, T. E. (1991). Eimeria palumbi, a new coccidian parasite (Apicomplexa: Eimeriidae) from the galapagos dove (Zenaida galapogoensis). Transactions of the American Microscopal Society, 110(2), 178-181. doi: 10.2307/3226755

Natala, A. J., Asemadahun, N. D., Okubanjo, O. O., Ulayi, B. M., Owolabi, Y. H., Jato, I. D., \& Yusuf, K. H. (2009). A survey of parasites of domesticated pigeon (Columba livia domestica) in Zaria, Nigeria. International Journal of Soft Computing, 4(4), 148150. doi: ijscomp.2009.148.150

Ogedengbe, J. D., Hanner, R. H., \& Barta, J. R. (2011). DNA barcoding identifies Eimeria species and contributes to the phylogenetics of coccidian parasites (Eimeriorina, Apicomplexa, Alveolata). International Journal for Parasitology, 41(8), 843850. doi: 10.1016/j.ijpara.2011.03.007

Pérez-Tris, J., \& Bensch, S. (2005). Diagnosing genetically diverse avian malarial infections using mixedsequence analysis and TA-cloning. Parasitology, 131(1), 15-23. doi: 10.1017/S003118200500733X

Radfar, M. H., Fathi, S., Asl, E. N., Dehaghi, M. M., \& Seghinsara, H. R. (2011). A survey of parasites of domestic pigeons (Columba livia domestica) in South Khorasan, Iran. Veterinary Research, 4(1), 1823. doi: $10.3923 /$ vr.2011.18.23

Rathinam, T., Gadde, U., \& Chapman, H. D. (2015). Molecular detection of field isolates of Turkey Eimeria by polymerase chain reaction amplification of the cytochrome c oxidase I gene. Parasitology Research, 114(7), 2795-2799. doi: 10.1007/s00436-015-4546-4

Reid, A. J., Blake, D. P., Ansari, H. R., Billington, K., Browne, H. P., Bryant, J., .. Pain, A. (2014). Genomic analysis of the causative agents of coccidiosis in domestic chickens. Genome Research, 24(10), 16761685. doi: 10.1101/gr.168955.113

Sari, B., Karatepe, B., Karatepe, M., \& Kara, M. (2008). Parasites of domestic (Columba livia domestica) and wild (Columba livia livia) pigeons in nigde, Turkey. Bulletin of the Veterinary Institute in Pulawy, 52(4), 551-554. 
Shibatta, O. A., Galves, W., Carmo, W. P. D. do, Lima, I. P. de, Lopes, E. V., \& Machado, R. A. (2009). A fauna de vertebrados do campus da Universidade Estadual de Londrina, região norte do estado do Paraná, Brasil. Semina: Ciências Biológicas e da Saúde, 30(1), 3-26. doi: 10.5433/1679-0367.2009v30n1p3

Valkiūnas, G., Bensch, S., Iezhova, T. A., Križanauskienė, A., Hellgren, O., \& Bolshakov, C. V. (2006). Nested cytochrome $\mathrm{B}$ polymerase chain reaction diagnostics underestimate mixed infections of avian blood haemosporidian parasites: microscopy is still essential. Journal of Parasitology, 92(2), 418-422. doi: 10.1645/GE-3547RN.1

Valkiūnas, G., Iezhova, T. A., Križanauskienè, A., Palinauskas, V., Sehgal, R. N. M., \& Bensch, S. (2008). A Comparative analysis of microscopy and PCR-based detection methods for blood parasites. Journal of Parasitology, 94(6), 1395-1401. doi: 10.1645/GE-1570.1
Yang, R., Brice, B., Elloit, A., Lee, E., \& Ryan, U. (2014). Morphological and molecular characterization of Eimeria paludosa coccidian parasite (Apicomplexa:Eimeriidae) in a dusky moorhen (Gallinula tenebrosa, Gould, 1846) in Australia. Experimental Parasitology, 147, 16-22. doi: 10.1016/j.exppara.2014.10.010

Yang, R., Brice, B., Elloit, A., \& Ryan, U. (2016a). Morphological and molecular characterization of Eimeria labbeana-like (Apicomplexa:Eimeriidae) in a domestic pigeon (Columba livia domestica, Gmelin, 1789) in Australia. Experimental Parasitology, 166, 124-130. doi: 10.1016/j.exppara.2016.04.009

Yang, R., Brice, B., \& Ryan, U. (2016b). Morphological and molecular characterization of Eimeria purpureicephali n. sp. (Apicomplexa:Eimeriidae) in a red-capped parrot (Purpureicephalus spurius, Kuhl, 1820) in Western Australia. International Journal for Parasitology: Parasites and Wildlife, 5(1), 34-39. doi: 10.1016/j.ijppaw.2016.01.003 